\title{
HeIDEgGer AND BLUMENBERG ON MODERNITY
}

\author{
Teodor Negru ${ }^{1}$
}

\begin{abstract}
The debate surrounding the way in which Heidegger and Blumenberg understand the modern age is an opportunity to discuss two different approaches to history. On one hand, from Heidegger's perspective, history should be understood as starting from how Western thought related to Being, which, in metaphysical thinking, took the form of the forgetfulness of Being. Thus, the modern age represents the last stage in the process of forgetfulness of Being, which announces the moment of the rethinking of the relationship with Being by appealing to the authentic disclosure of Being. On the other hand, Blumenberg understands history as the result of the reoccupation process, which means replacing old theories with other new ones. Thus, to the historical approach it is not important to identify epochs as periods of time between two events, but to think about the discontinuities occurring throughout history. Starting from here, the modern age will be thought of not as an expression of the radicalization of the forgetfulness of Being, but as a response to the crises of medieval conceptions. For the same reason, the interpretation of history as a history of the forgetfulness of Being is considered by Blumenberg to subordinate history to an absolute principle, without taking into account its protagonists' needs and necessities.
\end{abstract}

KEYWORDS: Anthropology. Blumenberg. Heidegger. History, Modernity. Science. Technology.

\section{Determining Historical Epochs and the Problem of Modernity}

Raising the issue of approaching modernity from Heidegger and Blumenberg's different perspectives represents an opportunity to discuss two ways of approaching history. This means, on one hand, the interrogation with respect to how historical eras were constituted and how they legitimate themselves. Heidegger's perspective of identifying the ontological fundaments of historical eras is challenged by the idea that claims that historical events cannot be understood outside history, but only from the perspective of continuities

\footnotetext{
Faculty of Philosophy and Social-Political Sciences. Al. I. Cuza University of Iasi, Romania. theonegru@yahoo.com
} 
and discontinuities with the historical tradition. On the other hand, explaining the essential phenomena of modern age (science, technology, new condition of man, secularisation) from the two perspectives offers the possibility to discuss the expectations we have from the expectations we should have from the thinking area that opened after the end of modernity. The announcement of a new era characterised by its separation from the traditional metaphysical thinking and marked by an authentic thinking of the Being is considered to subordinate the diversity of history to an absolutist principle. In this context, the dialogue between Heidegger's and Blumenberg's conceptions opens a new space of reflection on the attitude we should have toward the modern era and toward the mechanism according to which changes happen in history.

According to Heidegger, history should be understood starting from how Western thinking relates to the Being (Sein). Beginning with Plato, this relation took the form of metaphysics, to which the understanding of the Being meant grasping the permanent given. However, such a way of questioning is not adequately to the Being because while searching for the durable and stable, we actually question beings (Seiende), leaving the question regarding the Being unthought. According to this line of thinking, history is no longer merely a succession of some events through time (Historie). But it should be understood starting from what opens in such events, which is from the Being (Geschichte). History becomes the destiny of the Being, where the term destiny should mean "sending" (schicken), a way of offering of the Being that discloses (geschehen) in each epoch in a determined way. Epochs are configured according to a certain understanding of the Being and, therefore, the delimitation from the perspective of historical events is considered irrelevant.

The history of Being means destiny of Being in whise sending both the sending and It which sends forth hold back with their self-manifestation. To hold back is, in Greek, epoché. Hence, we speak of the epochs of destiny of Being. Epoch does not mean here a span of time in occurence, but rather the fundamental characteristic of sending, the actual holding-back of itself in favor if the discernibility of the gift, that is, of Being with regard to the grounding of beings [...] The epochs overlap each other in their sequence so that the original sending of the Being as presence is more and more observed in different ways. (HEIDEGGER, 2002, p. 9).

As a process of the Being, history actually means forgetfulness of Being (Seinsvergessenheit), and the historical epochs represent various ways where the Being withdraws or discloses unauthentically as being. The history 
of the forgetfulness of the Being becomes synonymous with the "conversion of truth," to the extent that the truth is understood as the disclosure of the Being. The three epochs Heidegger speaks about, the antiquity (after the preSocratics), the Middle Ages, and the modern age, should be analysed from the perspective of forgetting the Being, meaning the more and more distancing from aletheia, from the pre-Socratic experience of the truth as unconcealment (Unverborgenheit) and from the original experience of the Being. These epochs should not be thought of as a continuous process as they form an "independent string" leading together to the consolidation of the forgetfulness of the Being and to the transition from the existence of man in the light of truth to the conception of truth as depending on human perception.

The history of forgetfulness of Being starts with the platonic interpretation of the Being as $i \delta \varepsilon \dot{\varepsilon} \alpha$. The shine emanating from $i \delta \varepsilon \dot{\varepsilon} \alpha$ makes visible the field of beings. This shine is what "[...] brings about presencing, specifically the coming to presence of what a beings in any given instance. A being becomes present in each case in its whatness" (HEIDEGGER, 1998, p. 173). In other words, in the Idea, being is grasped in its "visible form" $(\varepsilon l \delta o \varsigma)$, by gazing. Therefore, "formation" is important as well as "education" $(\pi \alpha \iota \delta \varepsilon l \alpha)$ through which gaze should become adequate in order to grasp the Idea correctly. The adequacy of the gaze and its correctness become criteria of the truth, which is now understood as the resemblance $(o ́ \mu \nu \omega \sigma l \xi)$ or correspondence (adaequatio) between assertion or representation and a thing. The understanding of the Being as $i \delta \varepsilon \dot{\varepsilon} \alpha$ marks the transition from a new conception of the truth that is no longer understood as "unconcealment",

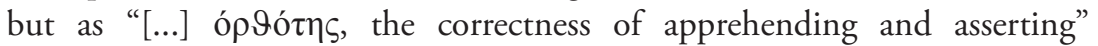
(HEIDEGGER, 1998, p. 177). Hence, starting with cu Plato, the truth is no longer regarded as unconcealment of the Being, but, to the extent that access to what is concealed is made by gaze, the correctness of such an act and its correct direction toward the Idea become the criteria of truth.

With Aristotle, the Being acquires a new determination, as it is understood

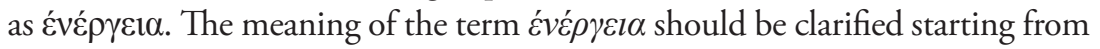
the root $\varepsilon \rho \gamma o v$, which means work, an efficient action presencing (anwesen) in unconcealment. 'EvÉ $\rho \gamma \varepsilon \imath \alpha$ is not the efficient reality resulting from a productive action, but it is "[...] the presencing, standing there in unconcealment, of what is set up" (HEIDEGGER, 2003, p. 5). Approaching the Being as consistency (Ständige) makes thus a step forward as compared to thinking the Being as 
visible form, in crystallising the metaphysics of the permanence that will wrongly orient toward knowing beings and not the Being.

The Middle Ages come with a new interpretation of the Being and of the truth from the perspective of the concept of empire, which builds reality on order and commandment. According to "imperial" essence of romanity, the truth is the right (rectus), meaning compliant with what is orderly. The Being has transformed now from évép $\gamma \varepsilon \imath \alpha$ into actualitas, referring to the real as such or truly real (actus purus), which fulfils itself in God, the supreme being. This is the meaning of the Being that would dominate the western thinking until the modern era.

The latest great epoch of the history (of forgetfulness) of the Being is the modern age, characterised by five essential phenomena: emergence of science, machine technology, aesthetics (" [...] the art work becomes the object of mere subjective experience, and that consequently art is considered to be an expression of human life" (HEIDEGGER, 1977a, p. 33), culture as man's supreme activity and desacralization (understood as a process of leaving aside the Christian conception of the world, in parallel with the transformation of the Christian vision with a view to adapting it to the reality of the modern age). In the modern age, the truth is understood as certainty, as awareness of knowledge, as its representation (Vorstellung). This conception of the truth offers a privileged position to man - as a subject, meaning the basis the entire reality relies upon. Reality and the subject are thought as being opposed (Gegensändige) to one another, and the presencing of the Being is only possible by means of its transformation into object, which requires a subject to represent it. This is the last but one step in the forgetfulness of the Being, which will culminate with delivering the Being as availability by Technology. Technology represents the fulfilment of all metaphysics, as it offers the means to dominate nature as standing-reserve (Bestand) man can manipulate.

To Blumenberg, any attempt to uniformise history, either in terms of interpreting it from the perspective of the event of the forgetfulness of the Being, or in terms of classical historiography of delimiting some historical eras, represents a failure in the understanding of the fact that history represents a plurality of questions and answers reflecting people's needs. History, now understood as history of ideas (Geistesgeschichte) no longer has to focus on "[...] the individualization of historical periods as complex unities of events and their consequences and the preference given to states rather then actions, to configurations rather then figures" (BLUMENBERG, 1999, p. 459). This is 
also suggested by the meaning of the Greek term "epoché," which refers to a break of a movement or even a reversed direction. In astronomical language, "epoche" refers to a privileged point wherefrom movement of a celestial body can be observed. To the historical approach, it is not important to identify epochs as periods of time between two events, but thinking the discontinuities occurring throughout history. Historical events are important not by their scope but insofar as they "[...] contain deep radical changes, re-evaluation and turnings, which affect the entire structure of life" (BLUMENBERG, 1999, p. 464).

Discussing historical inquiry, in Thomas Kuhn' terms, it should attach more importance to understanding how paradigms of thinking change, rather than to their consolidation. Paradigms wear out; they reach puzzles impossible to solve that lead eventually to forming other theories that replace the old thinking system. However, the theory of "scientific revolutions" does not explain how these mutations occur and what does happen within the framework of such changes.

In order to understand the transitions of history, we should accept the fact that all changes unfold due to a constant matrix of needs, which operates along the historical stages. This means that the quest for absolute beginnings in history is wrong, as the questions are forever the same. The interest for some of them may disappear in a period only to re-emerge later within a favourable context. What vary are the answers, which, owing to the contradictions reached by their latest consequences, determine the occurrence of the "reoccupation" process, i.e. replacing some theories with others.

The concept of "re-occupation" designates, by implication, the minimum of identity that it must be possible to discover, or at least to presuppose and to search for, in even the most agitated movement of history. In the case of systems of "notions of man and the world" "reocupation" means that different statements can be understood as answers to identical questions. (BLUMENBERG, 1999, p. 466).

The reoccupation process is not a gradual one. Even if it is heralded by some ideas, explored in isolation before the transformation proper takes place, the occurrence of the change as such remains imperceptible. The term of threshold of the epoch explains, on one hand, how the old theory exists before the threshold, and, on the other hand, we have the new theory that represents stepping over the threshold, without any intermediate steps in-between. This transition, Blumenberg highlights, is not guided randomly, but it is based 
on the needs system that may be found on both sides of the threshold. There is even an indicator of stepping over the threshold that consists of the formation of a new seriousness, by the attention paid to certain previously considered secondary questions. In the Middle Ages this seriousness referred to the preoccupation for reaching beatitude via faith, which had not existed in Antiquity; the seriousness of the modern age, contrary to medieval beliefs, was oriented toward cancelling traditional prejudice and revaluing experience as a source of knowledge.

The consciousness of a new seriousness puts the totality of the preceding attitudes, sympathies, and actions under the suspicion of frivolity; one had not yet found it necessary to take things so to heart, to be so particular, to want real knowledge." (BLUMENBERG, 1999, p. 473).

Starting from this perspective on history, whose moments are formed of convergent lines coming from the past, Blumenberg opposes the interpretation of modernity as an absolute beginning, meaning a complete break with the past with a view to creating novelty. Such a perspective cancels the legitimacy of the modern age, concealing the true reasons why it appeared.

[...] the program of the modern age cannot be assumed as a contingent "spontaneous generation"; the unfolding of its conceptual presuppositions already reflects the singular structure of the needs that had emerged, compellingly, in the self dissolution of the Middle Ages. (BLUMENBERG, 1999, p. 467).

The legitimacy of the modern age can neither be found in its interpretation as a result of a process of correcting the errors of the past, as it happens in its understanding from the perspective of the secularisation process. In this interpretation, the importance attached to certainty in the modern age is a secularisation of the Christian issue of the certainty of salvation; the modern ethics of labour is a secularisation of sanctity and of the different forms of ascetics; postulating political equality of all people is a secularisation of the idea of people's equality before God; the idea of progress is a transformation of the "salvation idea," and last, but not least, science is a secularisation of the vision of the world and of the intended actions of the original Christianity.

To this line of thinking, meaning the need to correct the negative consequences of the past, which influence the present, the interpretation of 
history as "history of Being" belongs as well. Even if Heidegger's approach of history avoids the mythology of the absolute beginning, it fails to legitimate the modern era by "[...] withdrawal into the comforting solidity of what was there all the long” (BLUMENBERG, 1999, p. 193). The consequence of this line of thinking of history is a negative idealisation of the modern era that relies on an a priori typification of the epoch, from whose perspective it is interpreted as the latest version of the "forsakenness of Being". Thus, the possibility to legitimate the modern era from a historical point of view is cancelled, preferring instead its characterisation as bearing

[...] the stigmata of domination, of the serviceability of theory for technicity, of man's self-production, precisely not as an "answer" to a provocation (bequeathed to it in whatever manner) but rather as one of the un-"graced" confusions surrounding the "Being" that has been withdrawn and concealed since the time of Pre-Socratics. (BLUMENBERG, 1999, p. 192).

The modern age cannot be explained merely as the result of a generalising process, such as the radicalisation of the inauthentic thought about Being, nor can it be treated as an absolute beginning without precedent in history. Its origin should be looked for in the dissolution of the medieval world, which, due to the contradictions of the theological absolutism doctrine - developed within the medieval nominalism - it generated the need for reoccupation of the scholastic thinking system. Self-assertion is a consequence of the contradiction expressed within the theological absolutism, between God's absolute will and man's will (which claimed to be free). Science is the result of a naturally human attitude -curiosity - that was arbitrarily excluded from the human authentic activities and which, objectivising itself, took the opportunity to manifest. Progress expresses confidence in the human being's abilities that by means of science and technology may understand nature and even master it. Hence, the modern age becomes legitimate by its discontinuities as compared to the past. It cannot be separated from the way the dissolution of the Middle Ages created the background for new answers to be formulated to the unsolved questions of the past.

\section{Modern Science and Technology}

Despite Heidegger including desacralization on the list of modern age features, he does not consider it defining for modern thinking. From the 
historial (Geschichtlichkeit) point of view, secularisation does not grasp the Being's understanding specific to the modern age. It is not a way to bring to presence the Being; it is merely a consequence of understanding the world in a way where religious explanations cannot find their place any longer.

The loss of the gods is a twofold process. On the one hand, the world picture is Christianized inasmuch as the cause of the world is posited as infinite, unconditional, absolute. On the other hand, Christendom transforms Christian doctrine into a world view (the Christian world view), and in that way makes itself modern and up to date. The loss of the gods is the situation of indecision regarding God and the gods. ( HEIDEGGER, 1977a, p. 116-117).

The essence of modern thinking lays in its relation to the Being by means of science and technology. What distinguishes modern science from the ancient and medieval ones is not any deep truth, but the approach of beings under the guise of research. Research implies the opening of a field of beings by projecting a new determined ground plan (Grundriss) on nature. By means of this ground plan, each process introducing itself as natural should be determined in spatial-temporal terms, i.e. it should be determined by number and calculation. The specific feature of the modern relation to nature is given by its mathematical character, whereby the essence of things is grasped from the outside, via the data we already possess. Thus, mathematics appears to be a way to acknowledge something setting-before. Therefore, calculation, which forms the essence of modern research, discloses beings as setting-before, as something that can be subjected at any time to re-presentation because it has been set before.

$T \alpha \mu \alpha \ni \eta \dot{\eta} \mu \alpha \alpha$ means for the Greeks that which man knows in advance in his observation of whatever is and in his intercourse with things: the corporeality of bodies, the vegetable character of plants, the animality of animals, the humanness of man. ( HEIDEGGER, 1977a, p. 118).

Another characteristic feature of modern science, as a historial process, is methodology (Verfahren), which implies clarifying the real by applying rules and laws that lead to objectifying the facts. This means looking for the necessities that guide changes in nature. From this perspective, one of the important consequences of science, understood as research, is that it is experiment-oriented, where by experiment we understand not only merely 
observing some facts, but a calculation questioning of the facts from the perspective of a law with a view to validating or invalidating such principle.

Lastly, the last determination of science under the guise of research is ongoing activity (Betrieb), which implies delimiting each field of beings, where each science is to be practiced. An effect of specialization is institutionalised research whereby science methodology asserts the prevalence over any being. Hence, science appears as a whole where the differences between natural sciences and humanities seem to fade due to the importance of methodology.

The historial consequence of modern science is not man's detachment from the framework of medieval thinking, but the transformation of the relation with the Being and beings which now takes the form of the certainty of representation. If during the Greek times, Being was the one that would open, and within this opening the encounter with man also occurred, in the modern age, beings exist only as man's subjective perception, which “[...] means to bring what is present at hand before oneself as something standing over against, to relate it to oneself, to the one representing it, and to force it back into this relationship to oneself as the normative realm" (HEIDEGGER, 1977 a, p. 131). Modern science is built up on standing-against (Vergegenständlichung) being, that is on the separation between subject and object. A consequence to such delimitation is that the subject by representing the object with a view to its immediate availability objectivises the entire beings, including itself.

The last stage of the forgetfulness of the Being is represented by modern technology, whose essence does not consist of producing ( $\pi 0 \imath \eta \sigma \iota \varsigma)$ as with the Greeks, but in setting-upon (stellen) nature with a view to its immediate challenging forth (Herausfordern).

The revealing that rules throughout modern technology has the character of a setting-upon, in the sense of a challenging forth. That challenging happens in that the energy concealed in nature is unlocked, what is unlocked is transformed, what is transformed is stored up, what is stored up is, in turn, distributed, and what is distributed is switched about ever anew. Unlocking, transforming, storing, distributing, and switching about are ways of revealing. ( HEIDEGGER, 1977b, p. 16).

Taking out from unconcealment, as "standing-reserve," is specific to technology. This means that Being does no longer reach presencing, not even as an object, but as something that is to be subjected to command. The character 
of standing-against of being has as a consequence the approach of being as standing-reserve, which should subject to command (bestellen). The subject-tocommand character that dominates the essence of modern technology and is referred to as Ge-stell (Enframing) is a result of understanding the reality as representation and of transforming nature by calculation, as setting-before (Vor-stellen). This means that modern technology is based on modern science, which contains this desire to deliver the Being with a view to subjecting it to command. However, technology represents no only the fulfilment of modern science, but the desire to subject the real as well, such desire is manifest in the entire metaphysics as it is the most radical way of the forgetfulness of the Being.

To Blumenberg, modern science is the result of freeing theoretical curiosity from the artificial constraints occurred throughout time for nature inquiry. Even if the theoretical attitude can be considered a constant in history, dating back to the beginnings of the Greek philosophy, Blumenberg refuses to turn it into the "destiny" of the western history. It is not the relation to the hidden principle of the Being what will clear the emergence of modern science, but understanding the historical circumstances, which determined the emergence of a self-conscious curiosity. In this case, understanding modern science is no longer carried out starting from the fact that it challenges forth nature to deliver itself in an inauthentic manner, but from how curiosity, as a "base instinct," pursuing the inessential and superficial matters, transformed under the constraint of the theories that had condemned that drive, in a reflexive attitude oriented to knowing the things and phenomena in this world.

In Antiquity, when man's inquiry prevailed all nature inquiry, theory was still seen as a way to reach happiness in life. However, this thing changed in the medieval era, when alongside the desire to secure happiness in the afterlife, the interest in salvation of the soul became more important than the one in nature inquiry. Rehabilitating the drive for nature inquiry was only possible when the possibility of the knowledge of the world we live in was asserted. In this case, it is no longer about asserting naïve curiosity, which characterises any human being, but it is about a "self-conscious" curiosity, which involved passing beyond the apparent things in order to inquiry methodically what happens in a universe open to man's eyes. From this perspective, the modern age represents the triumph of theoretical curiosity over other attitudes or ways of achieving fulfilment in life.

Just as "purity" as a quality of the theoretical attitude could only be formulated in the circumstances of Plato's opposition to the Sophists' 
instrumentalization of theory, so also the "right" to an unrestricted cognitive drive contituted itself and was united with the self-consciousness of an epoch only after the Middle Ages has discriminated against such intellectual pretensions and put them in a restrictive adjunct relation to another human existential interest posited as absolute. The rehabilitation of theoretical curiosity ar the beggining of the modern age is just not the mere renaissance of a life ideal that had already been present once before and whose devaluation, through the interruption of its general acceptance, had only to be reversed. (BLUMENBERG, 1999, p. 233).

The theoretical attitude appeared in the classical Greek epoch as a way man related to reality, without its being a result of a choice, as Husserl thought, from among many ways of understanding reality. The pre-Socratic man finds himself in the position of observer of the world, meaning that the universe opens before his eyes and he is invited to enjoy its contemplation. This contemplation of celestial bodies determines emancipation of the Greek spirit from the mythological explanations and the emergence of philosophy. Nevertheless, pre-Socratic thinking also contains the germ of the limits of theory claiming that what lies beyond appearance can only understood by the initiated. Moreover, Thales's story, who fell in a well while studying celestial bodies, heralds the conflict between the preoccupation for theory and the citizens' daily obligations, which in patristic literature would take the form of preoccupation for salvation instead of worrying about public duties.

In this context, Socrates sets the priority of inquiring man versus inquiring nature, which would distract the attention from the more important issue of man's integration in cosmos. If Socrates sets forth that philosophy should focus on the study of logic and ethics, Plato makes a step forward, by formulating the anamnesis theory, renouncing the difference between what should concern man and what distracts him from knowledge. Knowledge means discovering the truths existing in man, which secures his integration in the cosmic order. Aristotle refuses to associate the drive to know with selfknowing or with the moral action, considering it a natural drive coming from the perceptual access to the natural world, and not being related to any vital need of the human being. In this case, we are talk about knowing for one's own sake, which has no other goal than one's self-awareness, in compliance with man's natural instinct of recognising and understanding the truth.

In the Hellenistic period, curiosity was understood as a superfluous preoccupation, which extends man's cognitive capacities beyond what is 
possible to be known by man and useful to man. To the Stoics, curiosity was a disposition in agreement with our nature, which we cannot be ignored, but which also offers the drive to inquiry those vague and obscure objects. This idea appears in Seneca as well, who considers that owing to curiosity man wants to know more and more things succeeding thus to know the skies, as the highest object of knowledge. However, he recommends at the same time selfrestricted curiosity, which implies the risk of transforming into intemperance pushing us toward inquiring the objects that we cannot know. To Epicurus, who represents the second Hellenistic school, the appetite for knowledge is an important source of fear and hope, which cancels the chance to obtain happiness. Therefore, the preoccupation of philosophy will not be the basis of objective knowledge, but to remove all negative influences of the drive to know, which induce man's uncertainty. Philosophy becomes thus therapy to the extent that it assumes the role of correcting man's drives, which led him to an unhappy life. This idea can be found in the third Hellenistic school as well, scepticism, to which philosophy is a technique to remove obstacles that prevent us from being happy. In other words, happiness is what remains after we succeed in removing pain, curiosity, and the cognitive drive.

Augustine's conception is decisive to how man's natural propensity to knowledge was perceived in the Middle Ages. Against Gnosticism, which regarded knowledge as a condition of salvation, Augustine considers the cognitive drive a consequence of man's condition after the fall, including thus this drive among vices. Hence, curiosity becomes a temptation of the physical world, against which we must fight with temperance (in an expression he borrowed from Cicero). Curiosity as vice is described as exercising itself by means of the sensory organs, finding satisfactions in the most trivial objects, and that it consists of the appetite for sensual experience. Curiosity is repudiated because it is not an activity that would contribute neither to man's salvation nor to knowing God, but it is directed toward the things that nature does not make accessible to man. The theological conception of the universe is subordinated to a theological conception where the interest in man's salvation through faith emerges in the foreground.

The restriction of curiosity in medieval thinking is illustrated by the status of astronomy, as a subject that focuses on nature inquiry, as a liberal art, meaning a subject that says nothing about God. This idea is defended among others by Peter Damian as well, who considers that access to the divine truth cannot come from the philosophers' wisdom reflected in the liberal 
arts. The desire to know conceals man's desire to be God's equal and it is an attitude that results from self-asserted reason, which is only interested in securing "[...] the metaphysical conditions of the possibility of his objects" (BLUMENBERG, 1999, p. 328). Albert the Great supports the existence of some incongruence between the subjective cognitive drive and the objective need to know, asserting that inquiry into the objects that are irrelevant to man is a wrong intention in itself. In other words, the quest for knowledge of nature is due to the limited cognitive capacities of man, which determine him to ask questions about his needs and orient his cognitive drive toward accordingly. Thomas d'Aquino considers that theoretical curiosity reaches its ultimate fulfilment in knowing God, as a form of knowledge subordinating all other sciences. Nevertheless, curiosity, as knowledge of nature, is one of the forms taken by man's renunciation, after the fall, in knowing God. This feeling of acedia (indifference, apathy) characterising the man who ceased to believe in God, materialises in the diversion from activities proper to the human being, such as cura, actio, et labor (care, action, and labour). The re-evaluation of the theoretical curiosity at the end of the Middle Ages will start from this very theory of indifference to the absolute.

The vice of disregarding the preliminary character of this life was to be replaced by the conception of man's theoretical/technical form of existence, the only one left to him. From melancholy over the unreachability of the transcedent reservations of the Diety there will emerge the determined competition of the immanent idea of science, to which the infinity of nature discloses itself as the inexhaustible field of theoretical application and raises itself to the equivalent of the transcedent infinity of the Diety Himself, which, as the idea of salvation, has become problematical. (BLUMENBERG, 1999, p. 336).

The way curiosity was reflected in the medieval times can be also analysed from the perspective of the descriptions Dante and Petrarch offered of nature. In his Inferno, Dante describes the Odysseus's journey beyond Hercules's Columns, which will transform into the modern age's symbol of heralding a new beginning, which would surpass everything that had been known before. Petrarch tells of the emotions felt after reaching the peak of Mont Vertoux. In both cases, curiosity does not take the modern objective form of science. Dante's tale is nothing but a version of the quest for salvation, which marked the entire scholasticism, where the desire for knowledge requires transcendent legitimacy to be found beyond itself. Whereas Petrarch's approach on curiosity is done 
from the perspective of the distinction between what is necessary and what is superfluous as he claims to be "[...] stupefied and is angry with himself for his admiration of earthly things; he rests content with what he has been and turns his inner attention to himself" (BLUMENBERG, 1999, p. 341).

The rehabilitation of curiosity could be carried out only after renouncing the interpretation of the cognitive drive as the "care" manifested for superfluous issues, which consequently entailed re-positioning in the issue of salvation and the need to know the natural world.

The self -assertive character of the theoretical attitude eradicated the immediacy of contemplation, the meaningfulness of watching the world from an attitude of respose, and required the aggressive cognitive approach that goes behind appearances and proposes and verifies at least their possible constitution. Theoretical curiosity, and the confirmations that it was to provide for itself when it eas constituted as "science", could no longer appropiately be disqualified as superfluous. The question, which had become open in every respect, what one had to expect from reality did not (for instance) repress the medieval concern for salvation; rather it took over the position of the concern for salvation as the one thing left in which man could center his interest and form which he could derive attitudes. (BLUMENBERG, 1999, p. 346).

This was due to two preconditions. The former was the importance given by the nominalistic voluntarism to predestination, to the idea that man cannot do anything with respect to his salvation. The latter is the assumption that the world is no longer directly accessible to the man's knowledge, but we need to appeal to the hypotheses and concepts of reason. In both cases, the consequences of the nominalistic idea of the existence of a hidden God were important as they determined an active behaviour of man with a view to occupy the place held by divinity.

The plans of this hidden God, William Ockham said, cannot be known by means of reason, which consequently has no longer a role in man's salvation. Reason is the starting point of some knowledge, which should operate by hypotheses and give up any ideal of adequacy to the concepts and standards used. Still, the preparation for the legitimation of knowledge of nature is not completed in the nominalistic view by the acceptance of measurement and calculation as instruments of nature inquiry. The ancient idea that God laid out nature according to measure, number, and weight is now interpreted in terms of the hidden God: "[...] according to His measure, according to magnitudes 
reserved to Him and related to His intellect alone" (BLUMENBERG, 1999, p. 349). The idea that the world can only be known by means of God's measures, which cannot be known by man, lay at the basis of the non-assertion of science ever since the fourteenth century. Nevertheless, the ideal of the quantitative description of objects and the development of mathematical instruments and methods to carry out such description - instruments and methods - which would represent the basis of the scientific inquiry of nature in the seventeenth century - was heralded ever since that period.

The rehabilitation of measures and calculation begins with Nicolaus Cusanus, who considers them instruments specific to human knowledge that bring to light the constant proportions of things. However, they do not grasp the essential characteristics of things, but they discover the heterogeneous feature of things they inquiry, together with the inaccuracy of the spirit using them. The quantitative approach to nature remains but a human endeavour that can never reach nature's precision, the more so that numbers and geometrical figures are not the result of the contemplation of Ideas and Perfect Shapes, as with Plato, but products of our mind. Hence, Cusanus proclaims the autonomy of the theoretical endeavour against all purposes that, in the scholastic conception, would justify it. Thus, Cusanus heralds the thematisation of the method as an immanent means of justifying the theory, offering at the same time a positive interpretation of curiosity.

Another important moment of legitimising curiosity was represented by Copernicus, who, by introducing the possibility of universal knowledge, liberated the curiosity drive from the cognitive restrictions. The world Copernicus described is a world made according to man's rational principles, which means that it can be known by means of science. Thus, theoretical knowledge has a positive role, i.e. to orient human spirit toward understanding the world. Curiosity widens thus its scope of activity from what is above us to the terrestrial world and to what is beyond the surface of the earth. This extension is illustrated by Leonardo da Vinci, considered a promoter of pure curiosity owing to his interest in inquiring the varied creations of nature and his preoccupation for the proliferation of human inventions to the detriment of "ancient" explanations and submission to God.

Legitimacy of the modern age consists rather in accepting the manifestation of curiosity as scientific research of nature than in rehabilitating curiosity. This is due to the replacement of medieval prejudice as to knowing the world with other assumptions that have increasingly legitimised the 
theoretical attitude. Giordano Bruno celebrates knowledge as a form of deliverance of truth from this world where it lies imprisoned. Moreover, to him knowing nature and possessing happiness become identical. To Bacon, man's orientation toward science is one of the attributes bestowed by divinity whereas the self-restriction imposed by the Middle Ages is an underestimation of man's capacities. In this context, Bacon identifies the vice of indolence to be the one that determined man to content himself with the explanations offered by the tradition authority without inquiring nature, i.e. without progressing according to his own nature. The ideal of knowledge is no longer contemplation but we now speak of knowledge as an on-going process in need of constant progress.

If Bacon does not make the step toward mathematisation of nature, with Kepler and Galileo, nature's laws can be encompassed in mathematical formulae, which are the "essence of necessity." Consequently, God's mediation between man and reality, which guarantees the certainty of man's knowledge of reality, is therefore cancelled. Thus, they go further than Descartes, securing truth not by divine guarantee, but by means of mathematics, which offers evidence and access in knowing nature's and God's laws. In this case, we speak of man's knowledge equal to God's, knowledge that no longer needs transcendent justification as it can self-justify since it is the expression of necessity to which both man and God related.

Starting from this point, Galileo will show that it is not the programme of knowledge that legitimates the cognitive drive, but "[...] the function of consciousness of what lies before it at any given time, which gives everything that has been achieved the mark of finitude and provisionality" (BLUMENBERG, 1999, p. 395). Hence, Galileo objectivises curiosity, he detaches it from man's personality, he moves it away from the motivational forces of the psyche, and transforms it into the sign of science imperfection. In contrast with Descartes, Galileo considers that truth can be found outside the methods as well by accidental discoveries or by removing prejudice, wrongly considered definitive. Another way of asserting the legitimacy of unrestricted curiosity is represented by Galileo's use of the telescope in nature inquiry. Penetrating areas hidden from man's eyes until then determined a new position of man and a new perspective on nature. Thus, the telescope becomes

[...] a factor in the legitimation of theoretical curiosity precisly because, unlike any experimental intervention in the objects of nature, it could be adapted to the classical ideal of the contemplation of nature. The 
phenomena newly revealed by the telescope nourished and gave wings to the imagination, which sought to provide itself, by means of the "plurality" of the worlds, with continually self-surpassing limit conceptions of what was as yet undisclosed. (BLUMENBERG, 1999, p. 375).

Descartes' merit was to take the process of objectivising theoretical curiosity through, insisting on the necessity that some certain fundamentals be found to ground knowledge. He also insisted on the importance of methodology whose role is to secure all cognitive acts. Descartes dissociates curiosity from life and happiness - which later on will constitute the basis of the critique to the absolutism of the Cartesian theory - transforming it into a mere cognitive realisation that is carried out by science.

Modern science is not the result of a process unfolded throughout the entire western history. It is a result of the way curiosity was understood as a consequence of the restrictions imposed by the Middle Ages. Competing with other interests of man, curiosity could not be understood as it was in the ancient times, as a contemplation of the world, but, in order to explain what happens in nature, it had to become an objective enterprise compliant with the laws of reason. The history of these transformations shows that the dominating character of science, which Heidegger considers a consequence of the entire history of forgetfulness of Being, not represents the fulfilment of a way of relating to this world that had manifested in the previous eras. Subjecting nature is the sign of a new anthropological condition, the condition of the man freed from medieval constraints, who now can exercise his power over the real.

\section{Human Condition in the Modern Age}

The historial consequence of modern science was the introduction, via the idea of representation, of oppositive thinking, which separates subject from the object. Unlike the medieval times, the new position of man is not determined by a preset hierarchy, but it defined by its subject condition. Thus, beginning with Descartes, we witness a transformation of the meaning of the terms subject and object against the background of the introduction of mathematics as instrument in order to understand the reign of the Being of beings.

Until Descartes every thing present-at-hand for itself was a "subject"; but now the „I" becomes the special subject, that with regard to which all the 
remaining things first determinate themselves such [...] The word objectum now passes through a corresponding change of mening. For up to them the word objectum denited what was thrown up opposite one's men imaginery. I imagine a golden mountain. This thus represented - an objectum in the language of the Middle Ages - is according to he usage of the language today, merely something, "subjective". (HEIDEGGER, 1967, p. 105).

In this new significance, the subject should be understood starting from the Greek term $v$ ino - $\kappa \varepsilon \imath \varepsilon \varepsilon v o v$, which translates as "[...] that-whichlies-before, which, as ground, gathers everything onto itself" (HEIDEGGER, 1977 a, p. 128). The modern subject, owing to the fact that it is given beforehand as subjacent, is the one that will be the ground of the entire beings, or, according to well-known phrase, it is the measure of all things. This does not mean it has the same privileged relationship with the Being as the Greek used to have during the Classical period. To the latter, the relationship with the Being was a direct one because it was opened to man, which means that the submission of physis to its subjectivity was not necessary. Protagoras' assertion should be interpreted in this sense of moderation in approaching the unhidden, of limitation only to knowledge of what is human. In the modern age, one cannot speak of measure as calculating thinking, which established truth as a certainty guaranteed by method, wishes to grasp the entire reality in an image and make it available to the subject.

Man understood as subject is a result of the establishment, in the modern age, of mathematics as a measurement unit of all thinking. Nevertheless, mathematical thinking is an axiomatic thinking, which imposes the existence of some privileged sentences upon which the knowledge system is built. The subject appears thus as a privileged axiom as an absolute fundament all beings are built upon. The Cartesian principle "cogito, ergo sum" expresses precisely the characteristic of primordial being of man, who can dispose of the other beings. Moreover, man is grounded on certainy, which gives this characteristic to the entire world built thereupon. Even if Heidegger agrees that this certainty is the result of the secularisation of the salvation certainty in the Middle Ages, he says that it is defining for man only in the historial sense as a determined way of understanding being. This thing is also valid for understanding man as subject, which thus turns into a moment of the destiny of Being originating in the ancient times. 
The name subjectivity names the unified history of Beings, beginning with the essential character of Being as idea with competition of the modern essence of Being as the will of power. (HEIDEGGER, 2003, p. 48).

The historial modern man reveals himself as subjectivity, as the will of will, his destiny is to disappear with the domination of Technology over nature.

To Blumenberg, the interpretation given in the modern age to man's position as master of nature is not a consequence of the forgetfulness of Being, but it is the result of re-occupying a conception that could no longer be sustained. The modern age should be regarded as the second attempt to overcome of Gnosticism, after the failure of the first attempt in the Middle Ages. Gnosticism represented an answer to the problem of the existence of the evil in the world as it was inherited from the ancient times. The Gnostics replied that God's omnipotence cannot be claimed because this would mean to reach a contradiction between God's will to destroy the material world, which is evil in itself, and the divinity's preoccupation with man's salvation; hence, the postulation of two divinities, a good one and an evil one, which would explain the antagonistic dualism of forces in the world.

The official doctrine of Christianity did not agree with this idea, sustaining God's omnipotence and considering matter a result of creation, which had no co-existed with God. The answer to the problem of evil was the doctrine of free will, as Augustine formulated it, aimed at increasing man's responsibility for all the evil in the world rather than instituting man's freedom. The evil in the world is in fact a reflex of man's wickedness and does not exist in itself, independent from man. Man's wickedness comes from the original sin of which he can be pardoned by divine grace, i.e. predestination. The idea of predestination also contains the idea that man is responsible for the entire corruption in the world because, even if some may be saved, there are still many more that will be responsible for the evil. Thus, the price for removing the Gnostic dualism was God's transformation into a hidden God who is the absolute sovereign. In this world dominated by evil, which comes from man, man is discouraged in any attempt of correcting it while still being urged to focus his attention toward the salvation of his soul. This is the reason why selfassertion is not a consequence of the first attempt to overcome Gnosticism. 
Considering the modern age the second overcoming of Gnosticism is based on the disappearance of the medieval order and the assertion that the evil is a result of "facticity" that can be defined in relation with everything that does not let man live. In this context, self-assertion is defined as

[...] an existential program, according to which man posits his existence in historical situation and indicates to himself how he is going to deal with the reality surrounding him and what use he will make of possibilities that are open to him. In man's understanding of the world, and in the expectations, assessments, and significations that are bound up with that understanding, a fundamental change takes place, which represents not a summation of facts of experience but rather a summary of things taken for granted in advance, which in their turn determine the horizon of possible experiences and their interpretation and embody the "a priori" of the world's significance for man. (BLUMENBERG, 1999, p. 138).

The destruction of the old order is due to nominalism, which took the medieval conception of the world to the ultimate consequences. This determined the formulation of the self-assertion presuppositions by abandoning the idea of cosmos as creation meant for man and the return to the atomist theory, that hold the neutral character of the creation of the world as well as by reoccupying the divine will with matter developing according to its own pre-established laws, which determined the formulation of the mechanicist theory.

There were multiple consequences to nominalism: accepting the doctrine of creation out of nothing, the nominalists promoted the idea that God is not like a demiurge, carrying out a pre-established plan, but that His absolute will creates things from the infinite possibilities. Nevertheless, man can understand this diverse reality only by reducing it to "classificatory concepts" (BLUMENBERG, 1999, p. 153), whereby he imposes upon it his own order. Self-assertion originates in this "economy" of concepts man uses to understand the world (and not God, who can only be understood through faith). Meanwhile, the consequences of creation out of nothing were that man could no longer find salvation either in escaping from the transcendent (as the Gnostics) or in indifference (as the Epicureans) or in the simple inquiry of nature, which now seems infinite. Science and philosophy have contributed to offer the means to remove man's uncertainty from the world: science, on the one hand, by presenting itself as a means to exercise man's power over nature, and philosophy, on the other hand, by providing a "[...] method of 
assuring the material adequacy and competence of man's possession of the world" (BLUMENBERG, 1999, p. 158).

Another consequence of Nominalism's accepting of the divine omnipotence was to claim the existence of the plurality of worlds. The possibility of God's conception of several worlds, of which but one is actually carried out, led to cancelling the conception that the universe was created for man. Removing man from the privileged position he used to hold within creation triggered the increase of awareness of man's insecurity in this world. This feeling grew due to the consequences of the assertion of God's absolute omnipotence. To fully carry out such absolute omnipotence, God cannot restrict His forces no even to benefit man. Hence, the conception of the biblical God interested in man, who sacrifices Himself to save the latter, is replaced by the image of God defined only by His omnipotence and who became man not to save the man but to prove His omnipotence.

After asserting the teleological absolutism and the cancellation of the anthropocentric character of the universe, man's only solution was to find an immanent ground for reality to rely upon. The Cartesian cogito and the certainty Descartes looked for represent the final point of the process of securing man in the world and of searching for an alternative to salvation, which is no longer accessible to man.

The God Who had never owed man anything and still owed him nothing, the God Who in Augustine's theodicity left to man the entire burden of the blame for what is wrong in the world and kept man's justification concealed in the degrees of His grace, was no longer the highest and the necessary, nor even the possible point of reference of the human will. On the contrary, He left to man only the alternative of his natural and rational self-assertion, the essence of which Luther formulated as the "program" of antidivine self-deification. (BLUMENBERG, 1999, p. 178).

Hence, the Cartesian endeavour does not produce a secularisation of the certainty of salvation but it stands for a solution to overstep the bounds of this idea.

Asserting the divine omnipotence has as consequence the awakening of the interest in man's status in the world. Compared to God's greatness, the man is reduced to a few qualities, which become defining to man and assert his unique character among the other living creatures. The Cartesian cogito is the consequence of the reduction of man to his essential qualities, 
which also opens the ways for man to assert himself in this world. This is also proved by the importance given, within the Cartesian system, to freedom even from the certainty of knowledge. Introducing the hypothesis of the evil genius, as a radicalisation of the theological absolutism, by transforming God in the philosophical hypothesis of a spirit that can deceive us, Descartes wants to highlight that under these extreme circumstances, man has a minimum liberty, which consists of refraining from any form of theoretical expression. Man's freedom does not consist of the possibility to find grounds for any enterprise, but of giving up all grounds when he thinks they are misleading. Hence, error is an expression of man's liberty and not of God's will.

A god can prevent man from knowing a single truth, but he cannot himself bring about error, unless man for his part freely runs the risk of being deceived. So man is not free in that he has grounds for his action but rather in that he can dispense with gounds. Absolute freedom would be readiness and the ability to resign all interest in truth so as not to risk error. The structure of consciousness appears both transparent and at the disposal of its possesor, so that the dimension of prejudice can be suspended. For this approach great disappointments and corrections were in store, from historicism to psychoanalysis. (BLUMENBERG, 1999, p. 185).

Man's freedom to know means renouncing the deduction of the truths about the world from God's intentions, whose realisation can be seen all over in nature. This means "disappearance of inherent purposes," postulated by nominalism and building up knowledge on hypotheses, whereby "[...] the methodical freedom of arbitrarily chosen conditions" (Blumenberg, 1999, p. 184) is asserted. The hypothesis signifies objectivising the relationship with reality by creating the conditions for the hypothesis to be validated. Such conditions aim at searching the certainty of the conjectures we make about the world. Thus, the theory acquires autonomy, liberating itself from the status of contemplation of the world from the divine point of view, which aims at reaching happiness.

Giving up the qualitative approach of the cosmos also contributed to consolidating this process by reducing the universe merely to its material aspects, which can be explained by the mathematical instruments. Accepting the materiality of the world as well as its mathematisation are the expression of the search for some universal means in order to know the possible worlds, whereby natural phenomena and processes can be interpreted objectively by means of the same standards. 
The mathematisation of science started with the abandonment of the astronomical claim to explain the causes of the celestial bodies' movement. By assuming the status of a liberal art, astronomy moved closer to mathematics creating thus the premises for physics to be approached from the geometrical and arithmetical perspective. Moreover, it created the possibility of greater freedom of expression, which would be freed from the rigorous constraints of the Aristotelian science and to offer explanations about the way the celestial mechanism works.

Nature's materiality is a response to the doctrine of creation from nothing, which renders God's goals hidden to man. Facing a world that is no longer created for him and whose metaphysical principles cannot be known, man cannot but represent nature to himself according to his reason in order to serve his own needs. Hence, a new anthropological consciousness is born whereby man is offered the possibility of exercise his demiurgic activity on the world. Whether the world is the result of the development of original matter, which can be known and manipulated to benefit man, it means that man can assert his independence from the allegedly immanent goals of nature whose author is God. However, the teleological image of the world begins to be questioned together with the assertion of the world materiality, which suggests the idea that physical processes unfold incessantly. The idea of an "unfinished" world (Kant) contributes to strengthening the idea of man's independence from any imposed goals, suggesting thus that the self-assertion task, in this world at man's disposal, is endless.

The "unfinished world" is no longer on the way, of its own accord, to ever greater perfection, with the aim of bringing forth man at its point of culmination, who as the witness of its immanent power registers its history in the result only and does not experience and push forward the process. Progress now becomes a category with a noncosmic status, a structure of human history, not of natural development. The "unfinished world" becomes the metaphor of a teleology that discovers reason as its own immanent rule that up untile then had been projected onto nature. Only the mecanism of this projection is exposed does the history of the disappearance of inherent purposes enter the phase of conscious and deliberate destruction. (BLUMENBERG, 1999, p. 214).

Hence, there is a horizon of possibilities that now opens which man is invited to explore assisted by science and technology. Modern science is a modality of man's self-assertion by asserting the possibility of foreseeing and 
anticipating events as well as of the ability to alter or produce such events. Modern technology is the expression of these new circumstances man finds himself under situation, of reaching a "[...] new quality of consciousness" (BLUMENBERG, 1999, p. 135), which would allow him to act on the world. Both are means of man's self-assertion in a world freed from the inevitable goals introduced by the medieval order and not the expression of western thinking which by distancing itself from the Being undertook as its goal to dominate nature. The self-asserting task becomes thus infinite and implies finding that pre-established structure of the world, which may offer safe grounds to build the world rationally with a view to transforming the reality we live in.

\section{Conclusion}

To Heidegger, history acquires meaning only when relating to the Being and transforming its moments in landmarks of access to the Being. The quest for the destiny of the Being means approaching history as the destruction of the history of ontology (Destruktion der Geschichte der Ontologie) by means of which the way to conceal the Being along the centuries is revealed. This quest aims at announcing the moment of the rethinking the relationship with the Being by appealing to the authentic disclosure of the Being.

To Blumenberg, Heidegger's understanding of history leaves unquestioned the very principles of the development of history. Making appeal to a sense of history, which is beyond history itself, transforming all events in expressions of the forgetfulness of the Being, means to reduce history to a singular fact and to overlook the plurality of questions and answers, which gives dynamism to history. Equally, the emergence of authentic thinking of the Being, which would be the liberating consequence of some many epochs of perverting the understanding of the Being, appears to be a renunciation to history and to the quest for its legitimating questions. Heidegger's Being presents himself as the medieval hidden God, who subordinates the entire reality as a principle that eludes our knowledge. This position is characterised by Blumenberg as pseudo-theology that hides the continuation of the medieval absolutism by other means.

History does not mean the simple sequence of facts throughout time, but the questions and answers associated to such facts, which generate changes of the way to interrogation the world. Legitimating the historical epochs is done from the perspective of such questions and answers whose consequences 
determine the process of reoccupation. Therefore, it would be wrong to consider henceforth that changes of the perspective on the world occur by virtue of attaining a certain goal or that the process of reoccupation contains in itself the idea of an unavoidable end. The existence of a logic, which would explain all the mutations of ideas, not only cannot be sustained, but it is also dangerous in itself as it contains the hazard of a totalitarian view on history.

The epoch appears as an absolute fact - or better: as a "given"; it stands, sharply circumscribed, outside any logic, adapted to a state of error, and in spite of its immanent pathos of domination (or precisely on account of it) finally permits only the one attitude that is the sole option that the "history of Being" leaves open to man: submission. (BLUMENBERG, 1999, p. 192).

History is not a monolithic process; it is formed of discontinuities, which reflect the heterogeneous and autonomous character of the human beings participating to it. However, at the same time, historical events unfold within the same history; therefore, they cannot be interpreted as absolute beginnings without continuity with what happened before. Any idea comes to occupy a position released from other idea, either due to a contradiction reached or to a prioritised need. The game of reoccupation is what allows history to rid of its dominating character and deliver it rather as an expression of people's spontaneity and not of a hidden transcendent principle.

From this perspective on history, modernity cannot represent the moment of heralding a new epoch altogether different from what was before. Just as modernity did not represent, despites its claims, an absolute novelty, what comes after the modern age is not the beginning of a perfect future where history ended and alongside the reoccupation process as well. The ill-fated consequences of the quest for universality in the modern age have led to its dissolution and to activating the process of reoccupying those ideas, which had been looking for the subordination of reality to some unique principles, with ideas open to the understanding of the plurality and fragmentation of the world.

From this perspective, Heidegger's idea that history is a process oriented to its own fulfilment, transforms modernity into a moment that needs to be overcome in order to achieve a bright future, whose promise is immanent to history. To Blumenberg, who denounces the Heideggerian approach of history as absolutist, history is formed according to the ever-changing ideas that correspond to its protagonists' needs. Therefore, the legitimacy of the epochs is achieved by thinking of the discontinuity of ideas and of the process of 
reoccupation underlying the replacement of ideas. Modernity in this case is no longer a moment in fulfilling history, but it should be regarded as the starting point in thinking the discontinuities that legitimate the contemporary era.

ACKNOWLEDGEMENTS: This paper was made within the project "Developing the Innovation Capacity and Improving the Impact of Research through Post-Doctoral Programmes”, supported by the Sectorial Operational Programme Human Resources Development - Romania, under the number POSDRU/89/1.5/S/49944.

NEGRU, Teodor. Heidegger e Blumenberg sobre a modernidade. Trans/Form/Açäo, Marília, v. 35, n. 2, p. 93-120, Maio/Ago., 2012.

RESUMO. O debate em torno da maneira como Heidegger e Blumenberg entendem a idade moderna é uma oportunidade para discutir duas abordagens diferentes sobre a história. Por um lado, do ponto de vista de Heidegger, a história deve ser entendida partindo do modo como o pensamento ocidental se relacionava com o Ser, o que, no pensamento metafísico, tomou a forma do esquecimento do Ser. Assim, a idade moderna representa a última etapa no processo do esquecimento do Ser, que anuncia o momento de repensar a relação com o Ser apelando para a autêntica divulgação do Ser. Por outro lado, Blumenberg entende a história como o resultado do processo de reocupação, o que significa substituir antigas teorias com teorias novas. Logo, para a abordagem histórica não é importante identificar épocas como períodos de tempo entre dois eventos, mas de pensar sobre as descontinuidades que ocorrem ao longo da história. A partir dai, a idade moderna é pensada não como uma expressão da radicalização do esquecimento do Ser, mas como uma resposta as crises de concepçóes medievais. Pela mesma razáo, a interpretação da história como a história do esquecimento do Ser é considerada por Blumenberg para subordinar a história a um princípio absoluto, sem levar em conta as necessidades de seus protagonistas.

PALAVRAS-CHAVE: Antropologia. Blumenberg. Heidegger. História, Modernidade. Ciência. Tecnologia.

\section{REFERENCES}

BLUMENBERG, Hans. The Legitimacy of the Modern Age. Cambridge: MIT Press, 1999. BIRAULT, Henri. Heidegger et l'expérience de la pensée. Paris: Gallimard, 1978.

CAHOONE, Lawrence E. The Dilemma of Modernity: Philosophy, Culture and AntiCulture. Albany, NY: State University of New York Press, 1988. 
FERRY, Luc; RENAUT, Alain. Heidegger and Modernity. Chicago: University of Chicago Press, 1990.

HAAR, Michel. Heidegger et l'essence de l'homme. Grenoble: Millon, 1990.

HEIDEGGER, Martin. Die Frage nach dem Ding. Tübingen: Max Niemeyer Verlag, 1962. (HEIDEGGER, Martin. What is a Thing. Indiana: Gateway Editions, 1967).

HEIDEGGER, Martin. Die Zeit des Weltbildes. In: HEIDEGGER, Martin Heidegger. Holzwege. Frankfurt am Main: Klosterman, 2003, 8. Auflage (HEIDEGGER, Martin. The Age of the World Picture. In: HEIDEGGER, Martin. The Question Concerning Technology and Other Essays. New York \& London: Garland Publishing, 1977a).

HEIDEGGER, Martin. Die Frage nach der Technik. In: HEIDEGGER, Martin. Vorträge und Aufsätze. Tübingen: Neske, 1959 (HEIDEGGER, Martin. The Question Concerning Technology. In: HEIDEGGER, Martin. The Question Concerning Technology and Other Essays. New York \& London: Garland Publishing, 1977b).

HEIDEGGER, Martin. Platons Lehre von der Wahrheit. In: HEIDEGGER, Martin. Wegmarken. Frankfurt am Main: Klosterman, 1967 (HEIDEGGER, Martin. Plato's Doctrine of Truth. In: HEIDEGGER, Martin. Pathmarks. Cambridge: Cambridge University Press, 1998).

HEIDEGGER, Martin. Zur Sache des Denkens. Tübingen: Max Niemeyer Verlag, 1962 (Heidegger, Martin, On the Time and Being. Chicago \& London: The University of Chicago Press, 2002).

Heidegger, Martin. Die Metaphysik als Geschichte des Seines. In: HEIDEGGER, Martin. Nietzsche II. Frankfurt am Main: Klosterman, 1997 (HEIDEGGER, Martin. Metaphysics as History of Being. In: HEIDEGGER, Martin. The End of the Philosophy. Chicago: Chicago University Press, 2003).

PIPPIN, Robert B. Idealism as Modernism: Hegelian Variations. Cambridge: Cambridge University Press, 1997.

PÖGGELER, Otto. Martin Heidegger's Path of Thinking. New Jersey: Humanities Press International, 1995.

Recebido em: 10.09.2011

Aceito em: 27.01.2012 